\title{
CIENCIAS MARINAS
}

\section{Ciencias Marinas}

ISSN: 0185-3880

cmarinas@uabc.mx

Universidad Autónoma de Baja California

México

Perumal, $\mathrm{P}$.

The Influence Of Meteorological Phenomena On The Ecosystems Of A Tropical Region, Southeast Coast Of India: A Case Study

Ciencias Marinas, vol. 19, núm. 3, 1993, pp. 343-351

Universidad Autónoma de Baja California

Ensenada, México

Available in: http://www.redalyc.org/articulo.oa?id=48019306

- How to cite

Complete issue

- More information about this article

Journal's homepage in redalyc.org

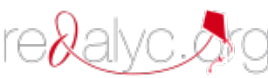

Scientific Information System 


\title{
THE INFLUENCE OF METEOROLOGICAL PHENOMENA ON THE ECOSYSTEMS OF A TROPICAL REGION, SOUTHEAST COAST OF INDIA: A CASE STUDY
}

\section{LA INFLUENCIA DE FENOMENOS METEOROLOGICOS SOBRE LOS ECOSISTEMAS DE UNA REGION TROPICAL, EN LA COSTA SURESTE DE LA INDIA: ESTUDIO DE UN CASO}

\author{
P. Perumal \\ Centre of Advanced Study in Marine Biology \\ Annamalai University \\ Parangipettai - 608502 \\ Tamil Nadu, India
}

Recibido en septiembre de 1992; aceptado en mayo de 1993

\begin{abstract}
The rainfall pattern at Parangipettai, southeast coast of India, for a period of a quarter century is given and the impact of rains on the hydrological and biological features is discussed. The total annual rainfall usually ranges between 1,200 and $1,400 \mathrm{~mm}$. Generally, the bulk of annual precipitation occurs during the northeast monsoon. The climate of the area can be divided into four seasons in one year: monsoon, postmonsoon, summer and premonsoon. The heavy monsoonal downpour and the resulting heavy freshwater flow through the river exert influence on the characteristics of the waters of the coastal region and its ecosystems. Wind velocity data are also given and the role of wind in the transport of organic matter and nutrients, and in mixing processes is been discussed.
\end{abstract}

\section{RESUMEN}

Se presenta el patrón de precipitación pluvial de Parangipettai, en la costa sureste de la India, para un periodo de cuarto de siglo y se discute el impacto de las lluvias en las características hidrológicas y biológicas. La precipitación anual total varía generalmente entre 1,200 y $1,400 \mathrm{~mm}$. La mayor parte de la precipitación anual suele ocurrir durante el monzón noreste. El clima del área puede dividirse en cuatro estacioncs: monzón, postmonzón, vcrano y premonzón. La fuerte precipitación del monzón y el intenso flujo de agua dulce resultante a través del río influyen sobre las caracteristicas de las aguas de la región costera y sus ecosistemas. Se proporcionan también datos de la velocidad del viento y se analiza la acción del mismo en el transporte de materia orgánica y nutrientes, así como en procesos de mezcla.

\section{INTRODUCTION}

Tropical coastal ecosystems are considered very important as they support a diversified biota and thus play a vital role in the nation's biological economy. A thorough knowledge of these ecosystems with reference to their meteorological and geographical features is a prerequisite for assessing their fertility and productivity, because the spatiotemporal pattern of precipitation, wind

\section{INTRODUCCION}

Los ecosistemas tropicales costeros son considerados muy importantes porque soportan una biota diversificada y juegan así un papel vital en la economía biológica de la nación. Un conocimiento minucioso de las características metereológicasy geográficas de estos ecosistemas es requisito fundamental para valorar su fertilidad y productividad, ya que el patrón espaciotemporal de precipi- 
velocity and the occurrence of extreme weather events impose regional constraints on agriculture and fisheries besides their impact on the natural ecosystems. Furthermore, the knowledge would help us in the protection, preservation, conservation and management of coastal ecosystems.

Recently, the International Council of Scientific Unions (ICSU) initiated efforts to study the global environmental change and has implemented long-term monitoring schemes, such as the International Geosphere-Biosphere Programme (IGBP) and World Climate Research Programme (WCRP), with the aim of developing a predictive model of the earth system and studying the physical aspects of the climate system. During the recently concluded Earth Summit in Rio de Janeiro, Brazil (United Nations Conference on Environment and Development, June 1992), consensus was reached on many global environmental issues, though after hot debate/conflict among the participants along the lines of North-South, developed-developing countries, etc.

Agrawal (1976) and Mukherjee and Singh (1978) have reported the monsoonal trends of the Asian subcontinent. Some short-term studies on environmental factors have been carried out for the Parangipettai region (Krishnamurthy and Sundararaj, 1973; Ramamoorthi and Venugopalan, 1981; Chandran and Ramamoorthi, 1984; Perumal, 1988). However, long-term studies are lacking for this region and, hence, an attempt has been made to know the pattern of rainfall and of wind velocity and their influence on the ecology of the Parangipettai region.

\section{STUDY AREA}

Parangipettai is situated on the southeast coast of India $\left(11^{\circ} 29^{\prime} \mathrm{N} ; 7^{\circ} 46^{\prime} \mathrm{E}\right)$, on the Bay of Bengal seaboard (Fig. 1). This coastal region is unique as it is abound with ecologically distinct aquatic biotopes, viz. Vellar estuary, Kille backwater, Pichavaram mangroves and the Bay of Bengal sea. These biotopes are rich in fin and shellfish resources and also serve as spawning and nursery grounds for many commercially important organisms. This place is one of the important fishing centres of the east coast of India. For the present study, the rainfall and wind velocity data, recorded by the local mete- tación, la velocidad del viento y la ocurrencia de cambios extremosos de clima imponen restricciones regionales a la agricultura $y$ pesquerías, además de tener impacto sobre los ecosistemas naturales. Este conocimiento ayudaría, consecuentemente, a proteger, preservar, conservar y manejar los ecosistemas costeros.

Recientemente, el Intemational Council of Scientific Unions (ICSU) ha iniciado esfuerzos para estudiar el cambio global del ambiente y ha organizado proyectos de observación a largo plazo, como el Intemational GeosphereBiosphere Programme (IGBP) y World Climate Research Programme (WCRP), con el fin de desarrollar un modelo predictivo del sistema Tierra y estudiar los aspectos físicos del sistema climático. Durante la reciente conferencia cumbre sobre la Tierra, efectuada en Río de Janeiro, Brasil (United Nations Conference on Environment and Development, junio 1992), se alcanzó consenso sobre muchos asuntos ambientales del planeta, aunque después de fuerte debate entre los participantes de las líneas de los paises del Norte y del Sur, desarrollados y en desarrollo, etc.

Agrawal (1976), y Mukherjee y Singh (1978) presentaron las tendencias del monzón en el subcontinente asiático. Algunos estudios a corto plazo han sido efectuados en la región de Parangipettai (Krishnamurthy y Sundararaj, 1973; Ramamoorthi y Venugopalan, 1981; Chandran y Ramamoorthi, 1984; Perumal, 1988). Sin embargo, se carece de estudios a largo plazo sobre esta región y, por ello, se ha hecho este intento por conocer el patrón de precipitación pluvial y velocidad del viento, así como su influencia sobre la ecología de la región de Parangipettai.

\section{AREA DE ESTUDIO}

Parangipettai está en la costa sureste de la India (11029' N; 79046' E), en el litoral de la Rahía de Bengala (Fig. 1). La región es única por la abundancia de biotopos acuáticos ecológicamente distintos: el estuario Vellar, el remanso Kille, el manglar Pichavaran y el mar de la Bahía de Bengala. Estos biotopos son ricos en peces y mariscos, y sirven también como campos de desove y cultivo para muchos organismos de importancia comercial. El lugar es uno de los centros pesqueros de la costa este de la India. Para el presente estudio, los datos de precipitación pluvial y velocidad del viento, 
Perumal: The influence of meteorological phenomena on the ecosystems of a tropical region

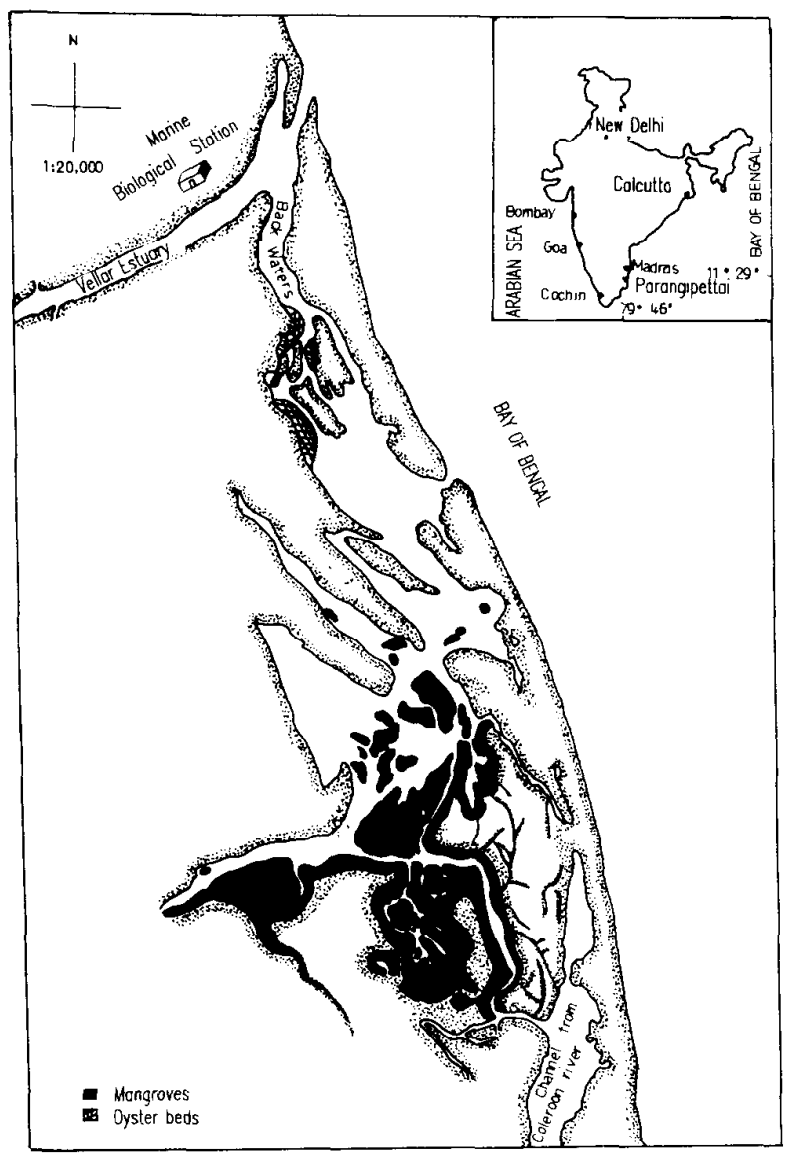

Figure 1. Map showing the Parangipettai (Porto Novo) coastal area, with India map inset.

Figura 1. Mapa del área costera de Parangipettai (Porto Novo), y su situación en el mapa de la India.

orological unit, were procured from the Government of India, Regional Meteorological Centre, Madras.

\section{RESULTS}

The rainfall values recorded during the periods of monsoon (October-December) and non-monsoon (January-September) for a quarter century are shown in Fig. 2. The monthly mean values of wind velocity for a period of twelve years are presented in table 1. The rainfall data recorded showed a pronounced sequence of variations. The years 1973, 1974, 1980, 1982 and 1984 are con- registrados por la unidad meteorológica local, fueron aportados por el Centro Meteorológico Regional del Gobierno de la India, en Madrás.

\section{RESULTADOS}

Los valores de precipitación pluvial registrados durante los periodos de monzón (octubre a diciembre) y no monzón (enero a septiembre) correspondientes a un cuarto de siglo, se muestran en la Fig. 2. Los valores medios mensuales de velocidad del viento de un periodo de doce años se listan cn la tabla 1. Los datos registrados sobre precipitación muestran una pronunciada secuencia de varia- 


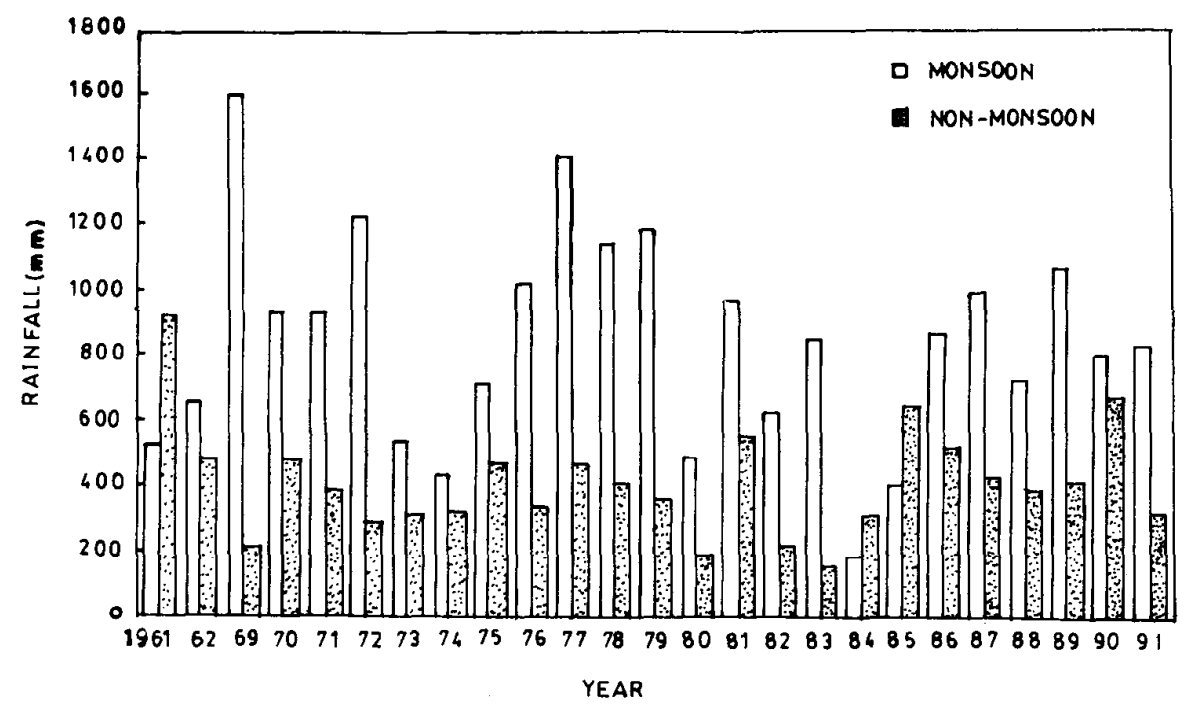

Figure 2. Rainfall values $(\mathrm{mm})$ of monsoonal and non-monsoonal periods during a period of a quarter century at Parangipettai (India).

Figura 2. Valores de precipitación pluvial $(\mathrm{mm})$ de los periodos monzónico y no monzónico, durante un cuarto de siglo, en Parangipettai (India).

Table 1. Monthly mean values of wind velocity $(\mathrm{km} / \mathrm{h})$ for a period of twelve years at Parangipettai (India).

Tabla 1. Valores mensuales promedio de velocidad del viento $(\mathrm{km} / \mathrm{h})$, correspondientes a un periodo de doce años, en Parangipettai (India).

\begin{tabular}{lccccccccccccc}
\hline Month & \multicolumn{10}{c}{ Year } \\
\cline { 2 - 14 } & 1980 & 1981 & 1982 & 1983 & 1984 & 1985 & 1986 & 1987 & 1988 & 1989 & 1990 & 1991 \\
\hline January & 8.10 & 5.70 & 4.00 & 0.39 & 1.10 & 1.87 & 0.45 & DNA & 5.10 & 5.61 & 6.30 & 5.06 \\
February & 3.30 & 2.20 & 4.10 & 0.71 & 1.64 & 0.43 & 0.14 & DNA & 5.76 & 5.04 & 7.17 & 5.14 \\
March & 5.40 & 6.40 & 6.20 & 0.97 & 0.58 & 3.55 & 0.26 & DNA & 7.87 & 9.23 & 7.38 & 3.83 \\
April & 6.90 & 7.90 & 7.10 & 3.00 & 1.33 & 8.40 & 0.53 & DNA & 8.07 & 8.53 & 6.30 & 7.90 \\
May & 9.00 & 9.10 & 7.30 & 4.77 & 4.87 & 10.26 & 2.58 & DNA & 9.00 & 8.42 & 7.19 & 9.35 \\
June & 7.50 & 8.70 & 6.90 & 4.73 & 4.73 & 9.27 & 1.07 & 7.77 & 10.47 & 8.43 & 7.00 & 9.96 \\
July & 6.60 & 7.70 & 6.80 & 5.29 & 2.06 & 5.42 & 1.26 & 9.26 & 6.90 & 7.86 & 6.93 & 3.51 \\
August & 7.30 & 7.10 & 6.50 & 4.26 & 2.39 & 4.65 & 2.97 & 8.35 & 6.29 & 7.13 & 5.60 & 5.96 \\
September & 7.60 & 5.70 & 6.30 & 4.00 & 2.07 & 5.80 & 3.47 & 7.63 & DNA & 6.63 & 5.66 & 8.86 \\
October & 4.90 & 3.80 & 3.10 & 3.10 & 2.52 & 3.03 & 0.26 & 5.00 & DNA & 5.58 & 5.16 & 5.03 \\
November & 5.50 & 4.20 & 3.70 & 1.07 & 1.13 & 0.45 & 2.47 & 4.47 & DNA & 6.30 & 4.30 & 6.50 \\
December & 5.90 & 5.80 & 5.70 & 2.26 & 4.13 & 1.03 & 1.65 & 6.03 & DNA & 6.67 & 6.74 & 7.09 \\
\hline
\end{tabular}

DNA: data not available. 
Perumal: The influence of meteorological phenomena on the ecosystems of a tropical region

sidered drought years, having recorded the lowest total annual rainfall of 865.9, 761.4, $672.1,830.5$ and $471.3 \mathrm{~mm}$, respectively. Higher values of rainfall were recorded during the years 1969, 1972, 1977, 1978, 1979 and 1981. The remaining years had the normal rainfall.

The percentage of rainfall during the different periods of each year showed that the highest values were always recorded during the months of October to December and that the lowest values, sometimes zero values, were recorded during the months of January to March. During some years (e.g. 1985), the monsoon sets-in a few months ahead of normal time. The highest values of wind velocity, 10.47 and $10.26 \mathrm{~km} / \mathrm{h}$, were recorded during 1988 and 1985 , respectively. In general, the intensity and duration of wind velocity was greater during the years 1987 through 1991.

\section{DISCUSSION}

The coastal seaboards of peninsular India receive considerable annual precipitation. The seasonal alterations of atmospheric pressure over the continent of Asia give rise to southwest and northeast monsoons. While the southwest monsoon is well distributed, the northeast one is normally torrents and accompanied by cyclones and floods. During the northeast monsoon, at times the daily rainfall exceeds $400 \mathrm{~mm}$ in a single day and the remaining part of the period has nil rainfall. This type of rain pattern causes serious setbacks and flooding along the coastal belt. The straight and wide opening of the Vellar estuarine mouth during the years 1977 and 1991 could be ascribed to the same reason.

The Parangipettai region experiences heavy rainfall during the northeast monsoon. The total annual rainfall in this region usually ranges between 1,200 and $1,400 \mathrm{~mm}$. This region also gets some rain during March to June owing to the repercussion of the southwest monsoon which sets on the west coast of India (usually between May and June). The climate of the study area can be divided into four seasons in one year. The seasons revolve round the monsoon and may be classified as follows: 1) monsoon (October to December), 2) postmonsoon (January to March), 3) summer (April to June) and 4) premonsoon (July to September)

The perusal of the rainfall data would show the vagaries in the onset and duration of ciones. Los años 1973, 1974, 1980, 1982 y 1984 se consideraron de sequía, en los que se registraron las menores precipitaciones totales por año, 865.9, 761.4, 672.1, 830.5 y $471.3 \mathrm{~mm}$, respectivamente. Los valores más altos de precipitación se registraron durante 1969, 1972, 1977, 1978, 1979 y 1981. El resto de los años considerados tuvieron precipitación normal.

El porcentaje de lluvia durante los diferentes periodos de cada año mostró que los valores más altos ocurrieron siempre durante los meses de octubre a diciembre y que los más bajos, algunas veces de cero, se registraron de enero a marzo. Durante algunos años (por ejemplo, 1985), el monzón aparece algunos meses antes de lo normal. Los valores más altos de velocidad del viento, $10.47 \mathrm{y}$ $10.26 \mathrm{~km} / \mathrm{h}$, se registraron durante $1988 \mathrm{y}$ 1985, respectivamente. En general, la intensidad y duración de la velocidad del viento fue mayor durante los años de 1987 a 1991.

\section{DISCUSION}

Las costas de la India peninsular reciben anualmente considerable precipitación pluvial. Las variaciones estacionales de la presión atmosférica sobre el continente asiático originan los monzones del suroeste y noreste Mientras el primero está bien distribuido, el segundo es normalmente torrencial y acompañado por ciclones e inundaciones. Durante cl monzón del noreste, la lluvia excede algunas veces $400 \mathrm{~mm}$ en un solo día y el resto del periodo tiene nula precipitación. Este tipo de patrón pluvial causa serios inconvenientes e inundaciones a lo largo del cinturón costero. La recta y amplia abertura de la boca del estuario de Vellar, durante los años 1977 y 1991 puede atribuirse a la misma razón.

La región de Parangipettai recibe fuertes lluvias durante el monzón noreste. La precipitación pluvial total en esta área usualmente es de 1,200 a $1,400 \mathrm{~mm}$. Esta región recibe algunas lluvias entre marzo y junio debidas a las repercusiones del monzón suroeste, el cual ataca la costa occidental de la India (usualmente entre mayo y junio). El clima del área estudiada puede dividirse en cuatro estaciones. Estas se rigen en torno al monzón y pueden ser clasificadas en: 1) monzón (octubre a diciembre), 2) postmonzón (enero a marzo), 3) verano (abril a junio) y 4) premonzón (julio a septiembre).

El examen de los datos sobre la precipitación pluvial mostraría las irregularidades sobre el comienzoy duración de los monzones 
monsoons. Based on the sequence of variations in rainfall, the pattern of annual precipitation can be classified as follows: 1) year of normal annual precipitation, 2) year of surplus annual precipitation, 3) year of flood and cyclones and 4) year of drought.

The decreasing trend of rainfall recorded and the occurrence of droughts during the latter part of the study period could be related to deforestation and the unsustainable pattern of industrial and agricultural activities. Meher-Homji (1980) correlated the rainfall pattern with forest density.

The percentage of rainfall obtained for the different seasons of the study period showed that the highest amount of rainfall in each year was recorded, as could be expected, during the (northeast) monsoon season and the lowest amount during the summer season. During the post and premonsoon seasons, the amount of rainfall was low. Superimposed upon the monsoonal pattern of precipitation of the year, we could observe the major differences in the succession of ecological events with broad two-base periods: (i) monsoon period (October to December) and (ii) non-monsoon period (January to September) (Fig. 2).

During the summer season, the biotopes are hydrographically stable and a steady increase in salinity could be observed. While the premonsoon season is a transient period, the postmonsoon season is considered a recovery period. The Vellar estuary is always connected with the sea. However, after prolonged drought years, particularly during the summer season, the normal alignment of this estuarine connection with the sea (established through the "mouth" of the estuary) is shifted away from its established position due to the sand bar formation (at the site of the original mouth). This would result in the meandering of the course of the estuarine mouth between 500 and $1,000 \mathrm{~m}$ away from its normal location. During the summer months, the estuarine, backwater and mangrove biotopes are dominated by the seawater and, during the monsoon period, they are influenced by the monsoonal flow of surplus fresh water.

Because of the torrential downpour and consequent shifting of position of the estuarine mouth with a straight course of connection with the sea, the hydrographical conditions here changed considerably (Perumal, 1988) During the years of normal and surplus annual
Con base en la secuencia de variaciones de la lluvia, el patrón de precipitación anual puede clasificarse como sigue: 1) año de precipitación anual normal, 2) año de precipitación anual excedente, 3) año de inundaciones y ciclones, y 4) año de sequía.

La tendencia decreciente de la lluvia registrada y la ocurrencia de scquías durantc la última parte del periodo de estudio pueden estar relacionadas con la deforestación y el insostenible patrón de actividades agrícolas e industriales. Meher-Homji (1980) relacionó el patrón pluvial con la densidad forestal.

El porcentaje de precipitación pluvial obtenido para las diferentes estaciones del periodo de estudio muestra que la mayor cantidad de lluvias en cada año se registró, como era de esperarse, en la estación del monzón (noroeste) y la menor, en el verano. Durante las estaciones post y premonzónicas, la cantidad de lluvias fue baja. Sobrepuestas al patrón monzónico de precipitación del año, se pueden observar las mayores diferencias en la sucesión de los eventos ecológicos, con dos amplios periodos básicos: el monzónico (octubre a diciembre) y el no monzónico (enero a septiembre) (Fig. 2).

Durante el verano, los biotopos son hidrográficamente estables y se puede observar un persistente incremento de salinidad. Mientras la estación premonzónica es un periodo de transición, la postmonzónica se considera periodo de recuperación. El estuario de Vellar está siempre conectado con el mar. Sin embargo, después de prolongados años de sequía, particulamente en la estación de verano, el alineamiento normal de esta conexión estuarina con el mar (a través de la boca del estuario) es desplazada lejos de su posición establecida, a causa de la formación de barra de arena (en el emplazamiento de la boca original). De esto resultaria el serpenteo del curso de la boca estuarina entre 500 y $1,000 \mathrm{~m}$ lejos de su ubicación normal. Durante los meses de verano, los biotopos de estuario, remanso y manglar son dominados por el agua de mar, y durante el periodo del monzón son influenciados por el flujo monzónico de agua fresca excedente.

Debido a los torrenciales aguaceros y el consecuente cambio de posición de la boca estuarina con trayectoria directa de conexión al mar, las condiciones hidrográficas cambian aquí considerablemente (Perumal, 1988). Durante los años de precipitación anual normal y 
Perumal: The influence of meteorological phenomena on the ecosystems of a tropical region

precipitation, this phenomenon of straight opening to sea occurs. The heavy downpour and the heavy freshwater flow through the river, concentrated during the three months of monsoonal rainfall in one year, exert influence on the characteristics of the waters of the coastal region and its ecosystems. The terrigenous drainage carried from the catchment area onward by the Vellar river, and also received en route as the river joins the sea at Parangipettai, enriches organic production in the ecosystems. Besides, the waters contained in the ecosystems acquire intrinsic properties and characteristics resulting from the varying degrees of mixing of the fluviatile and neritic water therein, coupled with tidal ebb and flow. Elliot and Wang (1978) studied the effect of meteorological parameters on the hydrodynamics of Chesapeake Bay and found interaction between estuarine and adjacent waters.

Among the various hydrographical parameters, salinity plays an important role in influencing species composition, prescribing tolerance limits for their growth, and in the distribution of chlorophyll, humic substances, trace metals, etc. (Mantoura and Morris, 1980; Lakshminarayana and Sitadevi, 1981; Cloern, 1984; Perumal, 1988; Perumal and Subramanian, 1989; Powell et al., 1989). The values of salinity of water are affected by the flow of estuarine water to the sea and vice versa, and by the pattern of annual precipitation. The monsoonal flows bring down the salinity to low concentration and during the summer season, the evaporation and neritic flow enhances the salinity level. The monsoonal fresh water carried the organic matter, humic substances, nutrientes, etc. to the estuary from the catchment areas of the upstream river (Hair and Bassett, 1973; Rajendran and Venugopalan. 1973; Perumal, 1988).

The high wind velocity recorded during the period of April to September could be ascribed to the southwest monsoon, which normally sets around June. Winds make waves and cause surface currents, water circulation and mixing. The surface currents of the ocean, in turn, influence the climate of the earth. Winstanley (1973) investigated the impact of rains and wind on the circulation pattern. The role of wind velocity in churning, transporting and piling up of bottom water and sediments, facilitating the release of organic matter and excedente, ocurre este fenómeno de abertura directa al mar. La copiosa precipitación pluvial y el abundante flujo de agua fresca a través del río, concentrados durante los tres meses de lluvia monzónica al año, ejercen influencia sobre las caracteristicas de las aguas de la región costera y sus ecosistemas. La corriente terrígena arrastrada desde el área de captación hacia adelante por el río Vellar, y también la recibida durante el recorrido del río hacia el mar, en Parangipettai, enriquece la producción orgánica en los ecosistemas. Además, las aguas contenidas en los ecosistemas adquieren propiedades y características intrínsecas según los diferentes grados de mezcla de las aguas fluviales o neríticas que conticnen, junto con la subida o baja de la marea. Elliot y Wang (1978) estudiaron el efecto de los parámetros meteorológicos sobre la hidrodinámica de Bahía Chesapeake y encontraron interacción entre las aguas estuarinas y adyacentes.

Entre los diversos parámetros hidrográficos, la salinidad desempeña un papel importante, al influir en la composición de especies, prescribiendo límites de tolerancia para su crecimiento, así como distribuyendo la clorofila, substancias húmicas, rastros de metales, etc. (Mantoura y Morris, 1980; Lakshminarayana y Sitadevi, 1981; Cloern, 1984; Perumal, 1988; Perumal y Subramanian, 1989; Powell et al., 1989). Los valores de salinidad del agua son afectados por el flujo de agua estuarina al mar y viceversa, asi como por el patrón de precipitación anual. Los flujos monzónicos llevan la salinidad a baja concentración y durante la estación del verano la evaporación y el flujo nerítico elevan el nivel de salinidad. El agua dulce del monzón arrastra materia orgánica, substancias húmicas, nutrientes, etc. al estuario desde las áreas de captación río arriba (Hair y Bassett, 1973; Rajendran y Venugopalan, 1973; Perumal, 1988).

La fuerte velocidad del viento registrada entre abril y septiembre puede atribuirse al monzón suroeste, que normalmente se inicia en junio. Los vicntos hacen olas y causan corrientes superficiales, así como circulación y mezcla de agua. Las corrientes superficiales del océano, a su vez, influyen en el clima. Winstanley (1973) investigó el impacto de lluvias y viento en el patrón de circulación. El papel de la velocidad del viento agitando, transportando y acumulando agua del fondo $y$ 
Ciencias Marinas, Vol. 19, No. 3, 1993

nutrients from sediments, in mixing processes and in the intensity of temperature and dissolved oxygen concentration has been emphasized by many workers (Zimmerman, 1976; Manzi et al., 1977; Sundararai, 1978: Cloern, 1984; Bhattacharya, 1987).

\section{ACKNOWLEDGEMENTS}

Thanks are due to $\mathrm{K}$. Krishnamurthy, for encouragement, to A.L. Paulpandian, Director, for facilities, and to the Director, Regional Meteorological Centre (Government of India), Madras-27, and S. Murugaiyan, Observer-local Meteorological Unit, for their help in getting the climatological data. Thanks are also due to $M$. Natarajan and K. Sanjeevi for their technical help.

\section{REFERENCES}

Agrawal, P.C. (1976). Variability and trend of annual rainfall in Chhatisgarh region, Madhya Pradesh. In: Proc. Symp. Tropical Monsoons. Indian Inst. Trop. Meteorol., Pune (India), pp. 465-470.

Bhattacharya, A. (1987). Interpretations on the pattern of wind and water movement over Long Sand from studies on texture and structure of the sediments. J. Mar. Biol. Ass. India, 29: 115-123.

Chandran, R. and Ramamoorthi, K. (1984). Hydrographical studies in the gradient zone of the Vellar estuary. II. Nutrients. Mahasagar, 17: 133-140.

Cloern, J.E. (1984). Temporal dynamics and ecological significance of salinity stratification in an estuary (South San Francisco Bay, USA). Oceanologica Acta, 7 : 137-141.

Elliot, A.J. and Wang, D.P. (1978). The effect of meteorological forces on the Chesapeake Bay: the coupling between an estuarine system and its adjacent coastal waters. In: J.C.H. Nihoul (ed.), Hydrodynamics of estuaries and fjords. Elsevier, Amsterdam, pp. 127-145.

Hair, M.E. and Bassett, C.R. (1973). Dissolved and particulate humic acids concentrations in an east-coast estuary. Estuar. Coast. Mar. Sci., 1: 107-111.

Krishnamurthy, K. and Sundararaj, V. (1973). A survey of environmental features in a section of the Vellar-Coleroon estuarine system, South India. Mar. Biol., 23: 229-237. sedimentos, facilitando la liberación de materia orgánica y nutrientes de los sedimentos, en procesos de mezcla y en la intensidad de la temperatura y concentraciones de oxígeno disuelto se ha enfatizado muchas veces ( $\mathrm{Zim}$ merman, 1976; Manzi et al., 1977; Sundararaj, 1978; Cloern, 1984; Bhattacharya, 1987).

\section{AGRADECIMIENTOS}

Se hace patente el agradecimiento a $\mathrm{K}$. Krishnamurthy, por su estímulo; a A.L. Paulpandian, Director, por las facilidades brindadas, así como al Director del Regional Meterological Centre (Gobierno de la India), Madras-27, y a S. Murugaiyan, de la Unidad Meteorológica de Observación Local, por su ayuda en la obtención de los datos climatológicos. Se debe agradecimiento también a M. Natarajan y K. Sanjeevi, por la ayuda técnica proporcionada.

Mora.

Traducido al español por Olivia Gómez

Lakshminarayana, J.S.S. and Sita Devi, J. (1981). Perspective of environmental impact assessment on marine resources. J. Mar. Biol. Ass. India, 31: 20-27.

Mantoura, R.F.C. and Morris, A.W. (1980). Chemistry of Swansea Bay. II. Spatial heterogeneity and processes. In: M.B. Collins et al. (eds.), Industrialized embayments and their environmental problems. Pergamon Press, Oxford, pp. 453-463.

Manzi, J.J., Stofan, P.E. and Dupuy, J.C. (1977). Spatial heterogeneity of phytoplankton population in estuarine surface microlayers. Mar. Biol., 41: 29-38.

Meher-Homji, V.M. (1980). The link between rainfall and forest clearance: case studies from western Karnataka. Transaction of the Institute of Indian Geographers, 2: $59-65$.

Mukherjee, A.K. and Singh, B.P. (1978). Trends and periodicities in annual rainfall in monsoon areas over the northern hemisphere. Indian J. Met. Hydrol. Geophys., 29: 441-447.

Perumal, P. (1988). Heterogeneity of coastal ccosystems with special reference to mangroves. Ph.D. thesis, Annamalai University, $156 \mathrm{pp}$. 
Perumal: The influence of meteorological phenomena on the ecosystems of a tropical region

Perumal, P. and Subramanian, P. (1989). Photosynthetic pigments and humic acids in tropical coastal board ecosystems. Ciencias Marinas, 15: 67-77.

Powell, T.M., Cloern, J.E. and Huzzy, L.M (1989). Spatial and temporal variability in South San Francisco Bay (USA). I. Horizontal distribution of salinity, suspended sediments and phytoplankton biomass and productivity. Estuar. Coast. Shelf Sci., 28: $583-597$.

Rajendran, A. and Venugopalan, V.K. (1973). Distribution of dissolved, particulate and mud phosphorous in Vellar estuary. Indian J. Mar. Sci., 2: 13-18.
Ramamoorthi, K. and Venugopalan, V.K. (1981). Distribution of salinity and mixing patterns in the Vellar estuary. J. Mar. Biol. Ass. India, 18: 461-468.

Sundararaj, V. (1978). Hydrographical studies in the Vellar-Coleroon estuarine system. Ph.D. thesis, Annamalai University, $111 \mathrm{pp}$.

Winstanley, D. (1973). Rainfall patterns and general atmospheric circulations. Nature, 245: 190-194.

Zimmerman, J.T.F. (1976). Mixing and flushing of tidal embayments in the western Dutch Wadden Sea. Part I. Distribution of salinity and calculation of mixing time scales. Neth. I. Sea Res., 10: 149-191. 